\title{
Developing sustainable green ship recycling facilities in Indonesia: Investigation of current situation
}

Fariya. S

Department of Naval Architecture, Ocean and Marine Engineering, University of Strathclyde, Glasgow, UK

Department of Naval Architecture and Shipbuilding, Adhi Tama Surabaya Institute of Technology, Indonesia

Gunbeyaz. S A

Department of Naval Architecture, Ocean and Marine Engineering University of Strathclyde, Glasgow, UK

Kurt. R E

Department of Naval Architecture, Ocean and Marine Engineering University of Strathclyde, Glasgow, UK

Sunaryo. S

Department of Naval Architecture, University of Indonesia, Indonesia

Djatmiko E B

Department of Naval Architecture and Shipbuilding, Sepuluh Nopember Institute of Technology, Indonesia

ABSTRACT: When ships reached the end of their operational life, they are required to be dismantled in a safe and environmentally friendly manner. However, current ship recycling process in Indonesia is not compliant with the standard of existing rules and is not environmentally friendly and dangerous to the safety of the workers. In this paper, a comprehensive gap analysis was conducted through the comparison of the current process with the standard of international regulations from health and safety perspective. The analysis is based on the expert judgement technique that combined the field observation and questionnaire to assess the current process as well as to identify the process related gaps compared to the current regulations. This has been achieved through these major steps: (1) Identification of ship recycling process, (2) Established an expert team, (3) Development of ideal process (4) Field observation (5) Development of observed process flow (6) Identify the gap.

\section{INTRODUCTION}

Shipping is the most important transportation method in the world condisdering around $90 \%$ of world trade is carried by the shipping industry. Therefore, so many ships built and operated around the world. When ships get older not only the operational running costs increase but also, they struggle to meet the requirements of new regulations. The recycling of ships at the end of their economic life has great significance for the continual renewal of the merchant marine fleet (White \& Molloy, 2011) and for sustainable development (Sundelin, 2008). In 2002, International Maritime Organization (IMO) ventured into a new territory by embracing the regulation of ship recycling, bringing new rules for ship owners as well as for ship recycling facilities. The International Convention on the Safe and Environmentally Sound Recycling of Ships (Hong Kong Convention) was adopted in 2009. The regulation is expected to come into force in coming years and it is a concern for Indonesia because the Indonesian fleet is old, but there are no ship recycling facilities which comply with the guidelines, to recycle them (Fariya, 2016). Therefore, the outputs of this study will fill an important gap through process flow mapping which is can be used to improve the conditions of the ship recycling yard to become green and sustain in terms of health, safety and environment.

\subsection{Ship Recycling}

According to IMO, ship recycling means the activity of complete or partial dismantling of a ship at a ship recycling facility in order to recover components and materials for reprocessing and reuse, whilst taking care of hazardous and others materials, and includes associated operations such as storage and treatment of components and material on site, but not their further 
processing or disposal in separate facilities (MEPC.21063-IMO guidelines, 2012)

Occupational health and safety have been a highly discussed and controversial topic within the ship recycling industry. In the past, a public image of secrecy, stubbornness and an overwhelming reluctance to change has been felt by the international community from the ship dismantling industry (Kurt et al, 2013). The major problem is that the use of beaching method during ship recycling in Indonesia without regarding health and safety, and environment aspects (Makbul, 2010). At the end of a ship's life cycle, the ship contains not only various recyclable materials but also a range of hazardous materials (HAZMAT) and toxic substances (Krause, 2005). The HAZMAT can be found in various sections of a ship such as; paint, insulation materials, toxic cargo and fuel residues, etc. Due to the upcoming new rules, a purpose-built ship recycling yard is necessary for Indonesia which will fulfil the international and national guidelines. Moreover, by establishing safe and environmentally sound ship recycling yards which are compliant with international regulations, Indonesia can take a bigger share from this emerging green ship recycling market.

\subsection{Ship Recycling in Indonesia}

One of the major Indonesian ship recycling yards located in Madura Island In general, ship recycling yards in Indonesia conduct their activities without offering proper protection for the environment and health \& safety. Moreover, due to the remote location of ship recycling yards, this industry is not enough known in Indonesia. So far, ship breaking in Indonesia is done in an unprofessional manner by businesses who lack the ability, awareness and infrastructure to be able to conduct appropriate ship recycling activities. Therefore, current ship recycling activities in Indonesia cause harm to the workers involved, surrounding environment (air, soil and water pollution) as well as to the public health through contaminating the food chain. This underdeveloped industry has the potential to develop into a major industry at a national and global scale (Fariya, 2016). Development of ship recycling important for Indonesia as they currently operate a large fleet of old vessels and most of these vessels are expected to be decommissioned in near future (BKI, 2014).

\subsubsection{Basel Convection}

In 1989, 105 countries and the European Union signed the Basel Convention on the Control of Transboundary Movement of Hazardous Waste and Their Disposal (Kummer, 1995). The Basel Convention was the international community's response to incidents of indiscriminate final disposal or dumping in developing countries by others. The applicability of the Basel Convention to ships sent for recycling is resting upon three element - first the ship has to classified as waste; second, they have to be subject to transboundary movement; and third, both the state of export and the state of import have to be parties to the Basel convention (Engels, 2013). These difficulties in the implementation of Basel convention leads to the development of the Hong Kong Convention which specifically designed for ship recycling.

\subsubsection{Hong Kong Convention}

The aim of the Hong Kong Convention is to ensure that the ships recycled at the end of their lives do not pose any unnecessary risk to human health and safety or to the environment. It is following six guidelines:

1. Guidelines for the Development of the Ship Recycling Plan

2. Guidelines for the development of the Inventory of Hazardous Materials

3. Guidelines for Safe and Environmentally Sound Ship Recycling

4. Guidelines for the Authorization of Ship Recycling Facilities

5. Guidelines for the Survey and Certification of Ship under the Hong Kong Convention

6. Guidelines for the inspection of Ships under the Hong Kong Convention

\subsubsection{EU ship recycling regulation}

In general, the main aim of this regulation is to support the early implementation of the Hong Kong Convention. EU ship recycling regulation was adopted by the European Parliament and the Council of the European Union on $20^{\text {th }}$ Nov 2013 and entered into force on $30^{\text {th }}$ Dec 2013.

\section{CONCEPTUAL APPROACH: SHIP RECYCLING PROCESS FLOW}

\subsection{The ship recycling process in Indonesia}

It is important to understand about the characteristic of a system before going to observation. The characteristic of ship recycling process can be seen below.

\subsubsection{Complex procedure}

Ship recycling activities are divided into three zones; offshore, inter-tidal, and onshore. The recycling process consists of several steps, such as cleaning, de-coating, cutting an additional processes such as hazmat and waste handling. In general, the ship recycling yard doesn't have a proper standard operational procedure, so it makes the process more dangerous by increasing the uncertainty in type of tasks that are conducted. 


\subsubsection{Safety critical process}

Ship breaking is recognized as one of the most hazardous occupations (ILO, 2004). Safety precautions in ship breaking yards in developing countries are notoriously scarce, accident rates are high and deaths frequent, whether by falling from a height, explosions, toxic fumes, snapping cables or other causes. Investigation of occupational noise exposure in a ship recycling yard showed that ship recycling workers are at risk of experiencing occupational noise and there is a lack of appropriate hearing protection being used in ship recycling yards (Kurt et al., 2017).

\subsubsection{Uneducated workers}

Poor and unskilled workers are deployed by the thousands to break down the ships manually. Training and awareness programs for the workers will help them raise their voices against being exploited.

\subsubsection{The yard owner is not good in safety understanding}

Based on the field observations, in general, the yard owner doesn't provide personal protective equipment (PPE) for the workers.

\subsection{Comprehensive gap analysis}

Comprehensive gap analysis for ship recycling industries includes: (1) Identification of ship recycling process, (2) Established of experts team, (3) development of ideal process based on the guideline (4) field observation (5) development of observed process flow (6) Identify workflow process gap. Fig. 2 outlines these steps, which we refer to as phases. Details for each phase are found below.

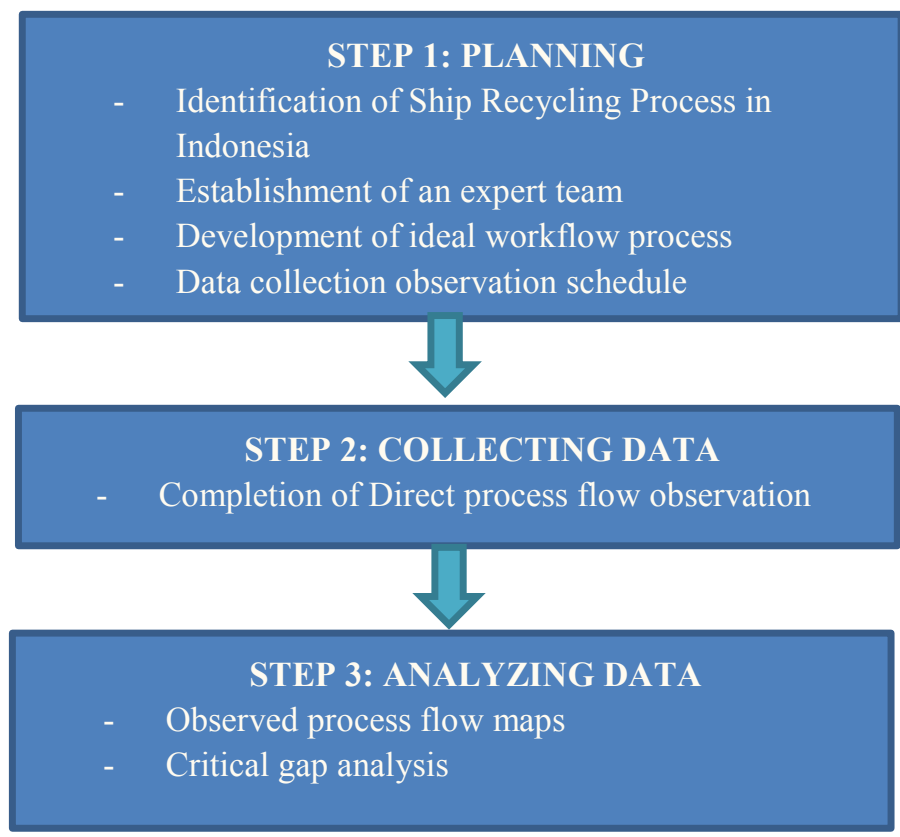

Figure 2. Gap analysis phases

\subsubsection{Phase 1: Planning}

\subsubsection{Identification of Ship Recycling Process}

There are four main processes observed in Indonesian Ship Recycling Industry; preparation, cutting process, lifting process, material management. In general, ship recycling yards in Indonesia conduct their activities without offering proper protection for the environment, and health \& safety. Most of the yards are a small business and they lack the ability, awareness, and infrastructure to be able to conduct appropriate ship recycling activities.

\subsubsection{Establishment of an expert team}

An expert team which is consist of the following personnel: (1) Ship recycling experts from academia, and (2) Local ship recycling experts, is established to develop process flow and created yard assessment to find comprehensive gap.

2.2.1.3 Development of ideal process based on the guideline

Ideal process should be created for each activity. Ideal workflow process map is created to represent the idealistic based on best practices and published in the international guidelines (IMO). To develop the ideal processes, the expert team should first identify the fundamental working

For this paper, a full ship recycling process was investigated. In this study, ship recycling process was observed for a 48-meter cargo ship which is recycled in Madura Island, in Indonesia. The ship dismantling process took part between 10th September 2018 22nd September 2018.

\subsubsection{Phase 2: Collecting Data}

2.2.2.1 Completion of direct process flow observation The process flow is established as shown in figure 3. The detail of step by step ship recycling activities can be shown below.

\section{(1) The Ship arrival and administration}

Before sending a ship for recycling certain documents should be prepared. The documents include:

- Sale and purchase certificate, this file serves to make sure the ship is not related to a specific case of dispute.

- Gross Tonnage certificate (GT)

- Certificate of deletion of registration of the Ship. Deletion of these files can be obtained from the office of the local port, where the ship registered. The existence of this file shows that the ship shall not be operated.

\section{(2) Preparation}

After the documents are prepared, the end of life ship will be transferred to the yard. Usually, the machinery 
is still working so the ship can be docked using its own power. Once the ship reaches the yard, the yard will prepare for the docking process. The process of docking is done using the beaching method, so the tidal sea level influencing the process to raise a portion of the ship to the ground. The cutting process is done at the time the ship was in tidal zones. The ship is sunk by utilizing the difference in tides. It is carried out using its own engine. In the process of cutting, a block of iron or other ship equipment is carried out in areas of intertidal zones. It is because the facility does not have a pier, jetty or intertidal crane. This procedure is repeated until the end of the cutting process.

\section{Cleaning and Primary Cutting}

Once the ship is ready for cutting process, the workers will start to do the cutting job. They clean and cut the ship at the same time. At this stage, the ship will be cleaned from the combustible materials such; paper, ropes and fuel oil in order to reduce the potential for fire and explosions during the process of ship breaking.

The cutting procedure performed without de-coating process which potentially poses a work accident in the form of fire. Stages of cutting the ship is done as follows:

1. Ships come in, after going through the process of the administration, it will be pulled a shore using a winch from the front of the ship.

2. After the cleaning process, the cutting is performed on two points: the bow and deckhouse. The cutting bow aims to open access to the ship to the ship body cutting activities. Meanwhile, cutting the bridge beginning aims to make ships in a State of balanced (even keel) during the cutting process

3. The next cutting work performed on the side of the ship at the same time, between the portside and starboard. This is done in order to maintain the even keel of the ship.

\section{(4) Secondary Cutting}

After being cut in the primary cutting zone, the part of the ship will be delivered to the secondary zone for a smaller cut. The metal scrap resulting from cutting in general size $100 \mathrm{~cm} \times 80 \mathrm{~cm}$. However, the size returned at the request of the consumers. The main consumer for this business is the largest nail producer in Indonesia. The smaller the size of the pieces of scrap metal that is being asked, the more expensive the cost of cutting will be. This is due to the increased gas consumption and increased worker time for additional cutting.

There is no flooring concrete in the secondary cutting zone, the spatter from cutting machine will directly come to the land. During the cutting process,
(5)

\section{Segregation}

The segregation process is for pieces of steel, reuse material, and waste. At this stage, garbage, waste and hazardous materials are mixing together without any separation. There is no storage to store garbage, waste and hazmat.

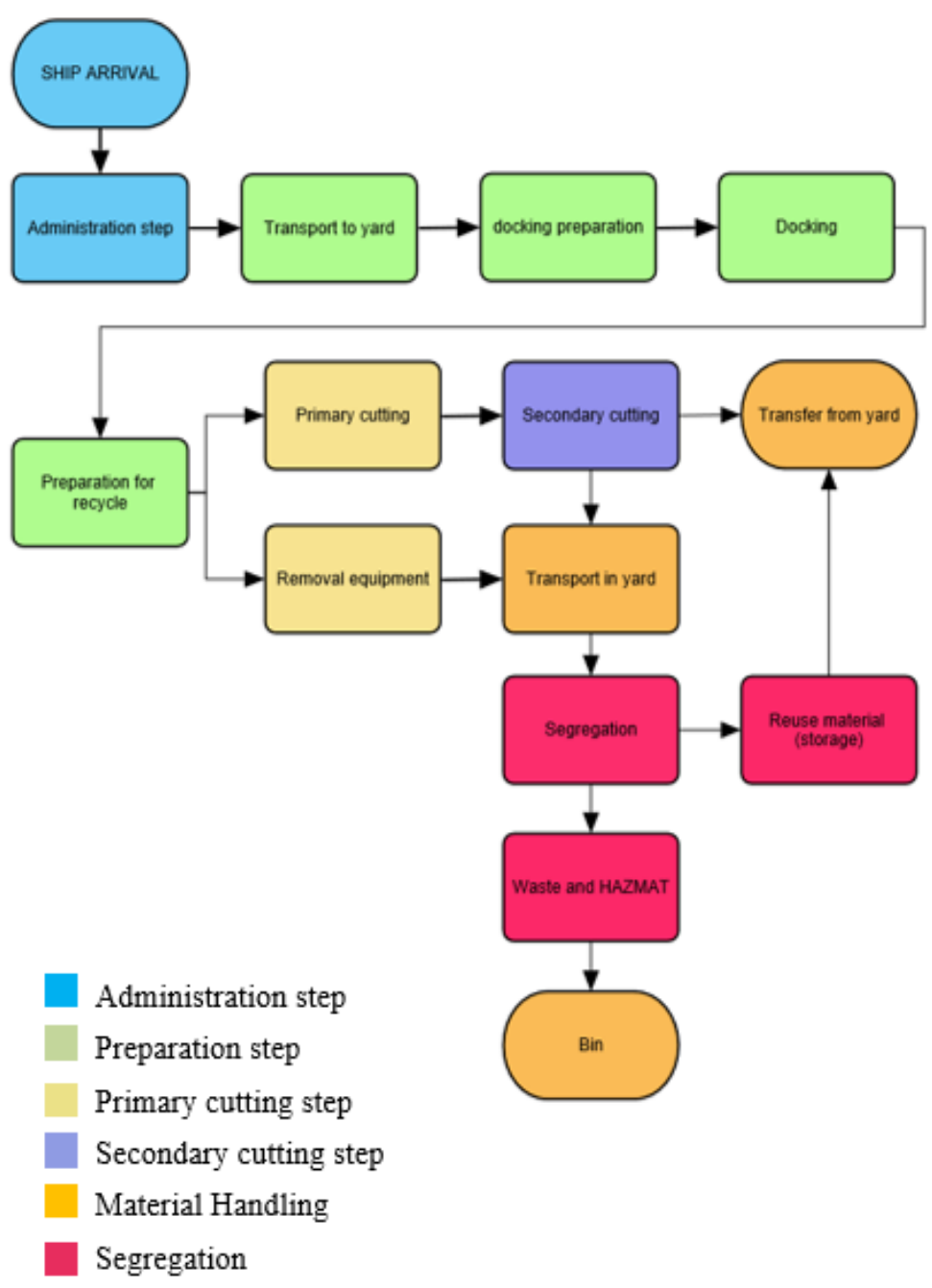

Figure 3. Indonesian Ship recycling processes flow

\subsubsection{Phase 3: Gap Analysis}

\subsubsection{Questionnaire Design}

As mentioned above, gap analysis is defined through expert judgement. There are two international and three local ship recycling experts who are chosen because of their knowledge and experience with Indonesian ship recycling. Questionnaire is delivered to collect expert opinion to assess the current process as well as to identify the gaps compared to the current laws and regulations. The detail of expert can be seen below.

Table 1. The detail of Ship recycling Expert

\begin{tabular}{|c|c|c|}
\hline Expert & Background & Year of expertise \\
\hline $\begin{array}{l}\text { International } \\
\text { Experts } 1\end{array}$ & $\begin{array}{l}\text { Academic and } \\
\text { industry }\end{array}$ & 10 years \\
\hline $\begin{array}{l}\text { International } \\
\text { Experts } 2\end{array}$ & $\begin{array}{l}\text { Academic and } \\
\text { industry }\end{array}$ & 5 years \\
\hline Local Experts 1 & Academic & 4 years \\
\hline
\end{tabular}




\begin{tabular}{|l|l|l|}
\hline Local Experts 2 & Industry & 8 years \\
\hline Local Experts 3 & Academic & 1 year \\
\hline
\end{tabular}

The results of this analysis will be used to support the roadmap for continued growth and development of the ship recycling industry in Indonesia. There are 14 questions, based on the International Maritime Guideline. For this paper, the questions are focused to cover the process flow and, in the scope, will be expanded in a future study to cover other aspects of the yards as well. Experts are asked for their opinion to give a score for the compliant of current ship recycling process in Indonesia with IMO guideline. Five score start from not compliant at all (1) till fully compliant (5) have become the choice for expert

\subsubsection{Questionnaire Result}

The result of questionnaire shown as figure 4 . According to expert's view, the process of ship recycling in Indonesia does not comply with the guideline yet, as all the score are below the middle score (3).

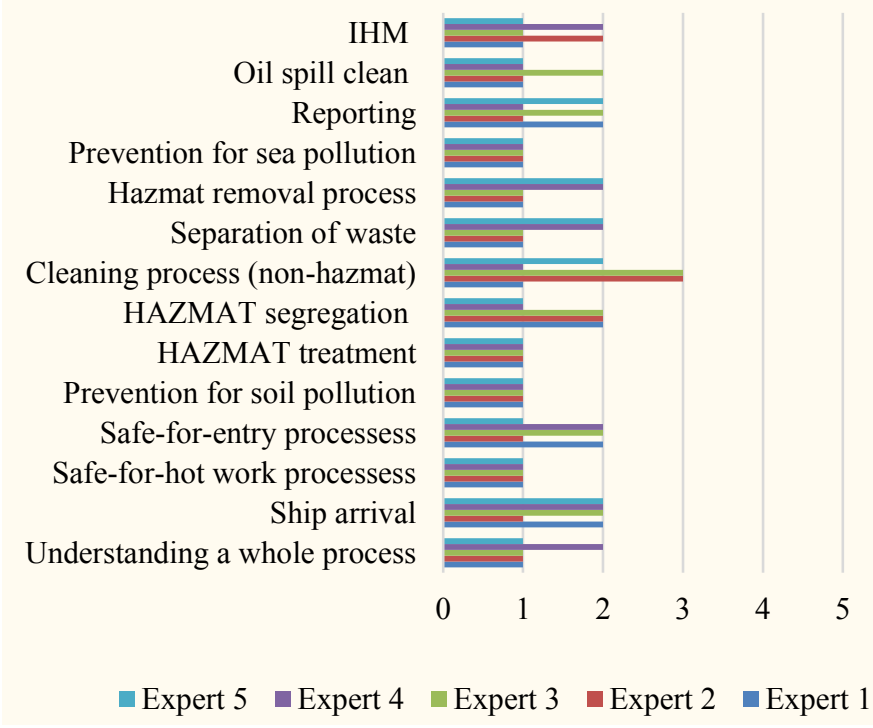

Fig 4. Experts opinion for each process

The total average point of 14 question answered by experts is 1.4 means that experts think that the Indonesian ship recycling industry is almost not compliant with the regulation at all. Figure 5 shows the rank of judgement score and there are four processes as they obtained the lowest score (1)/ not compliant at all with the ideal process:

1. Safe-for-hot-work process

2. Prevention for soil pollution

3. HAZMAT treatment

4. Prevention for sea pollution

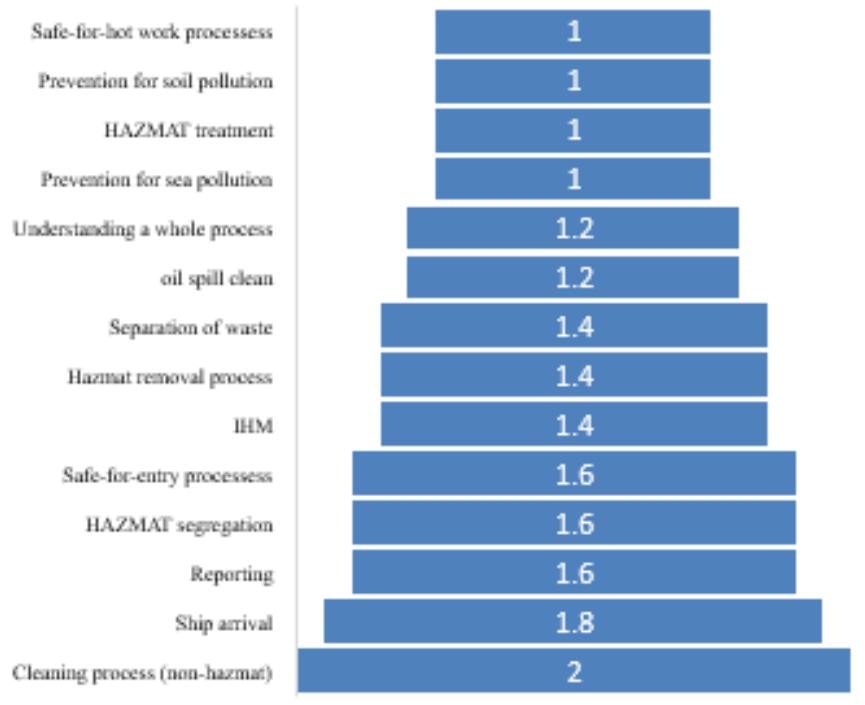

Fig 5. Average judgement score

\section{DISCUSSION}

\subsection{Updated process model}

The analysis is performed through expert judgement technique that combines the field observation and questionnaire to assess the current condition as well as to identify the process related gaps compared to the current laws and regulations. Figure 6 shows the updated process model with additional process below:

1. Technical and IHM survey.

The ship recycling or ship owner should prepare the technical and IHM survey for the purposes of identifying the type, location and quantity of any Hazardous Materials and for marking and/or labeling. Asbestos, PCBs, other Hazardous Materials and ship tanks such as crude oil tank (COT), fuel oil tank (FOT), lubricating oil tank (LOT), fresh water tank (FWT) and water ballast tank (WBT) should be clearly marked in an easily identifiable manner.

2. Preparation for recycle.

The prevention of sea and soil pollution should be included in the preparation step. For example: The installment of oil boom around the ship to prevent oil spill.

3. Safe-for-entry and safe-for-hot-work procedures.

Throughout the entire recycling process, the Ship Recycling Facility process ensure that, prior to entry and during work, enclosed spaces and other areas where the atmosphere is dangerous are monitored to ensure that they remain safe-for-entry and safe for work continued activity. The Ship Recycling 
Facility should ensure that shipboard spaces are not entered until a Safe-for-entry certificate has been issued by a Competent person. A Competent person should visually inspect and test each space on the ship to determine the areas which are safe for entry before issuing a certificate and before recycling activities are commenced, as well as safe-for-hot-work certification, inspection and testing which should be applied to the ship.

4. Waste and Hazmat treatment

The treatment process of hazardous materials and wastes should be applied after segregation. It should also include a detailed description of how recycled materials, reusable items and wastes are handled and/or disposed of in a safe and environmentally sound manner.

\section{Final Report}

When the recycling of a ship is completed, a completion report is to be issued including main particulars of ship, Statement of completion of ship recycling, qualification certificate of Ship Recycle Yard and Subcontractor, inventory of hazardous material handled etc. and reported to Competent Authorities. The report is to include detailed report, showing date, place, extent of damage, assumed cause and countermeasures, of incidents and accidents damaging human health and/or environment, if any happened in ship recycling process.

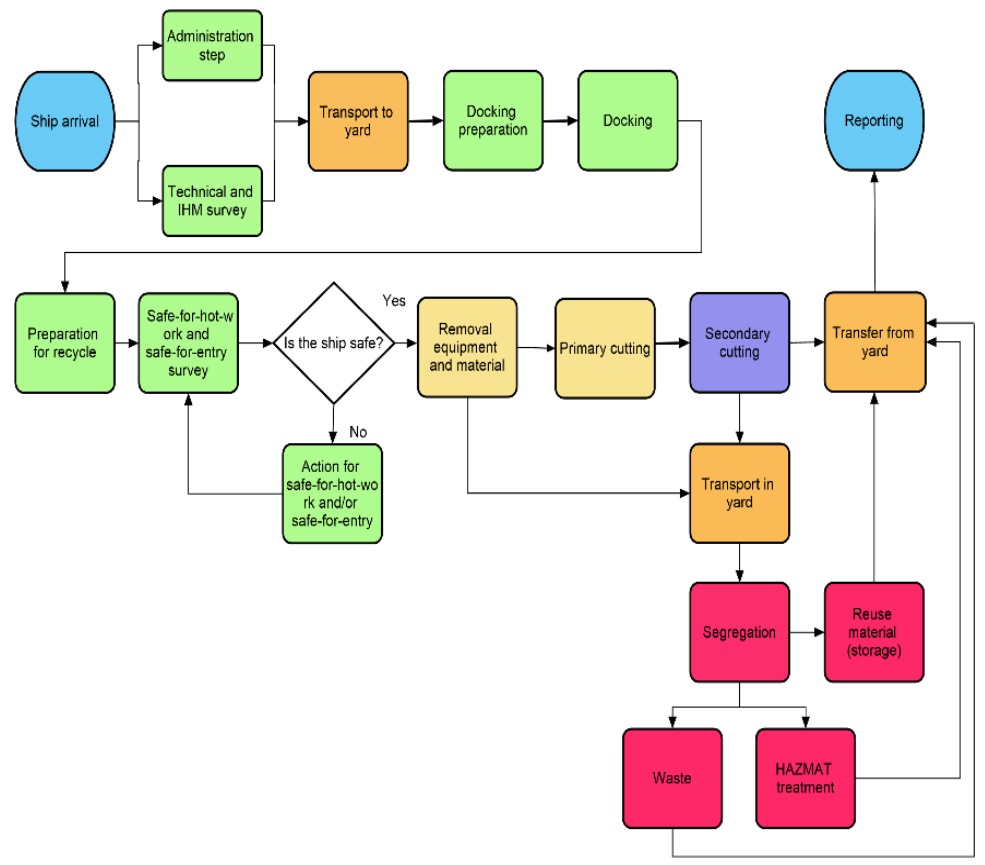

Fig 6. Updated process model

\subsection{Recommendation}

Based on the process related gaps found between the current state process flow and ideal process, the certain strategies to fulfill the gaps are advised below;

1. Facility Management

- Develop a specific document for job description and worker responsibilities, including qualifications, training and monitoring responsibilities.

- Improve the qualification of workers through relevant training.

- Create the vital record document for outline the policies and procedure, associated with facility operations and detail recycling process for each ship.

2. Facility Operation

- Prepare a written procedure contains the requirements for the acceptance of ship and describe the procedures to be implemented before the ship arrives.

- Develop the Ship Recycling Plan (SRP)

- Improve the facilities concerning the step below;

A. Pretreatment before cuttingB. HAZMAT and waste management facilities

- Conduct Inventory of Hazardous Materials survey by authorized person.

- Cooperate with authorized waste management place to deal with their treatment in environment sound manner

3. Worker Safety and Health compliance approach

- Develop workers health and safety plan.

- Prepare job hazard assessment document.

- Safe-for-hot-work and safe-for-entry Procedure.

- Provide a proper personal protective equipment for workers.

4. Environmental

- Develop the environmental monitoring program aimed at preventing possible negative impacts to the environment during ship recycling. Possible negative impacts during ship recycling may be divided into four main categories:

1. Releases of Hazardous Materials to ground and sediments; 
2. Releases of Hazardous Materials to water;

3. Emissions of Hazardous Materials to air; and

4. Noise/vibrations.

5. In addition, the related ministries (ministry of transportation, ministry of industry, ministry of environment) should be prepared for the guideline because there are lack of guideline and contradicting regulation between among the ministries.

\section{CONCLUSION}

The analysis is performed through expert judgement technique to assess the current process as well as to identify the process related gaps compared to the current situation shows that Indonesian ship recycling industries are doing their activities without regarding to the health and safety, and environment aspects as stated in regulation. The most critical gaps as they obtained the lowest point are (1) Safe-for-hot-work process, (2) Prevention for soil pollution, (3) HAZMAT treatment, (4) Prevention for sea pollution. This paper reported the results of gap analysis study which focused on ship recycling yard procedures only. It needs to be noted that the gap analysis is not complete as it does not integrate all requirements of international regulations. For example, technical capabilities of facilities were not investigated in this paper which will be addressed in a future study.

\section{ACKNOWLEDMENTS}

This research is conducted as part of a $\mathrm{PhD}$ study which is funded by Newton-RISTEKDIKTI Doctoral Scholarship in Maritime and Marine Science. Authors also recognize the opportunity created by Newton Institutional Links Grant project; Development of Green and Sustainable Ship Recycling Industry for Indonesia.

\section{REFERENCES}

Biro Klasifikasi Indonesia (BKI) as Indonesian Classification Society, 2014. CD Register.

Engels, U. D. 2013. European Ship Recycling Regulation: Entry-Into-Force Implications of the Hong Kong Convention, Heidelberg, Springer Science and Business Media. ISBN: 9783642355974

Fariya, S., Manfaat, D., Suastika, K., 2016, Technical Analysis of the Development of Ship Recycling Yard in Indonesia. The 2nd International Seminar on Science and Technology (ISST), Indonesia.
IMO 2011b. Guidelines for the development of the ship recycling plan. IMO (ed.) Annex 2 Resolution MEPC.196(62)

IMO 2012a. Guidelines for safe and environmentally sound ship recycling. IMO (ed.) Annex 2 Resolution MEPC.210(63)

ILO 2004. Safety and health in shipbreaking: Guidelines for Asian countries and Turkey. International Labour Organization, GenevaSwitzerland.

ISBN 92-2-115289-8

Jain, K. P., Pruyn, J. F. J. \& Hopman, J. J. 2017. Improving the Competitiveness of Green Ship Recycling, Rideerprint BV, The Netherlands. ISBN: 978-94-6299-657-1

Krause, K., 2005. End-of-life ships - linking European maritime safety to occupational safety on Asian scrap yards. Allsop, R., Beckmann, J., Mackay, G.M. (Eds.), ETSC Yearbook 2005, Safety and Sustainability. European Transport Safety Council, Brussels.

Kummer, K., 1995. International Management of Hazardous Wastes, Clarendon Press, Oxford.

Kurt, R.E., McKenna, S.A., Attila, B.D., Turan, O., 2013, Improving Occupational Health \& Safety Standards within the Ship Dismantling Industry through Accident, Incident \& Near Miss Investigation and Reporting. International Conference on Ship Recycling SHIPREC2013 - Malmö, Sweden.

Kurt, R. E., McKenna, S. A., Gunbeyaz, S. A. \& Turan, O., 2017, Investigation of occupational noise exposure in a ship recycling yard. Ocean Engineering, vol. 137.

Makbul, A. 2010., Studi tekno ekonomi pengembangan ship recycling yard di Indonesia, Tesis Program Magister Bidang keahlian teknik produksi dan material kelautan, Institut Teknologi Sepuluh Nopember, Indonesia.

Sundelin, O., 2008. The Scrapping of Vessels - An Examination of the Waste Movement Regime's Applicability to Vessels Destined for Scrapping and Potential Improvements Made in the IMO Draft Convention on Ship Recycling. Unpublished Master of Thesis. University of Gothenburg.

Welaya, Y.M.A., Naby M.A., Tadros, M.Y., 2012. Technological and economic study of ship recycling in Egypt. International Journal of Naval Architecture and Ocean Engineering.

White, I., Molloy, F., 2011. Ships and the marine environment. Maritime Cyprus 